\title{
KULTURPOLITIK OCH VÄRDEKULTUR
}

\section{Reflektioner kring UNESCO: s globala kampanj för kultur och utveckling}

\section{Per Råberg}

I UNESCO:s regi har under 1990-talet en kampanj bedrivits for att ge den kulturella dimensionen en mer framträdande plats i de politiska visionerna for det globala samhället. Flera kulturteoretiska perspektiv har diskuterats, bl.a. populärkulturens socialestetiska möjligheter. Ett annat centralt tema $i$ debatten är begreppet "hållbar utveckling», vars sociala och kulturella potential man önskar pröva. I denna artikel framläggs en kulturekologisk teori, som innebär ett värdekulturellt helhetsperspektiv i kulturpolitiken.

En satsning på värdekulturen skulle möjliggöra en upprustning av hela den humanistiska livssfären, som idag allvarligt hotas av de dominerande utvecklingskrafterna. Karaktäristiskt för den kulturekologiska ansatsen är att den försöker skapa en humanvetenskaplig kunskapsbas för sin samhällsvision. Den hävdar att kulturpolitiken först härigenom erhåller det solida fundament som är nödvändigt för storskaliga insatser $\mathrm{i}$ en ledande politisk position. Den ekologiska kulturteorin gör inte anspråk på en hegemonisk roll utan vill tillsammans med den traditionella konstkulturen och den sociala populärkulturen bilda en slagkraftig kulturell front mot samtidens tendens till en teknorationalistisk monokultur.
ARHUNDRADETS KULTURPROJEKT?

Teorier om kultur och utveckling får i hög grad sin karaktär av det temporala perspektiv som de omfattar. Divergerande teorier uppträder i debatten och konkurrerar om uppmärksamheten, men skiljaktigheterna mellan dem kan bero på att de outsagt valt olika tidsdjup för sina utvecklingsvisioner. Härigenom skapas en oavsiktlig mångfald som är förvirrande och ger ett inryck av bristande förmåga till strategisk samsyn. Men vad i denna mångfald beror på verkliga teoretiska skiljaktigheter och vad beror bara på differenser $\mathrm{i}$ det valda tidsbegreppet?

Reflektioner som dessa väcks osökt inför 
120 den idéinventering för en global kulturpolitik som bedrivits inom FN och UNESCO under 1990-talet. Dess främsta dokument är t.v. rapporten Our creative diversity (1995) som tillkom på initiativ av Världskommissionen för kultur och utveckling. En kompletterande belysning ges i flera andra skrifter, framför allt Europarådets studie In from the margins (1997). I varierande omfattning präglar tankegångarna också de deklarationer som senare formulerats (bl.a. av ministerkonferensen The power of culture i Stockholm 1998; Kulturpolitik för utveckling) liksom det förberedelsearbete som pågår inför ett förebådat världstoppmöte om kultur och utveckling. Det är ett ytterst ambitiöst och prestigefyllt projekt, som ställer kulturen $\mathrm{i}$ centrum för den internationella debatten om en agenda för global utveckling. Därmed är det ett initiativ till villket många humanister och intellektuella idag ställer förhoppningar. Kanhända kan det göra sig förtjänt av epitetet «århundradets kulturprojekt"».

Det beror i så fall på om man lyckas komma till rätta med de inre motsägelser som präglar projektet i dess nuvarande fas och som i första ögonblicket är mer ägnade att skapa frustration än klarhet om framtidskursen för en hållbar kulturell utveckling. Mot bakgrund av tidigare erfarenheter av offentlig retorik är det frestande för en universitetsman att skjuta texten åt sidan som ännu ett exempel på illusionsskapande maktlyrik. Men initiativet äger en seriös kärna och en ännu oexploaterad potential som motiverar att det blir föremål för en allvarlig ansträngning. En större förståelse kan uppnås om vi underkastar dokumenten en epistemologisk analys. Jag skall här göra ett försök att lösa uppgiften och inleder med att kommentera den temporala substrukturen.

\section{TEMPORAL TEXTANALYS}

En närsynt läsning av Our Creative Diversity avslöjar att det teoretiska och ideologiska programmet låter sig sorteras i åtminstone tre separata tidsparametrar: en evolutionär, en episk och en episodisk. Under den evolutionära parametern (som också kan beskrivas som paradigmöverskridande, i kortform: paradigmatisk) kan UNESCO:s initiativ tolkas som en maning till paradigmatisk uppgörelse med det moderna projektets teknorationalistiska samhällsvision, som utgör ett tilltagande hot inte bara mot den lokala och globala biomiljön utan mot den sociala och kulturella samhällskärnan. Uppgiften för ett globalt kulturprojekt är att återskapa den förlorade humanistiska värdedimensionen i samhället, och att därigenom lägga grunden för en rekonstruktion av den rubbade balansen i människans sociokulturella livssystem. Detta är ytterst den enda realistiska strategin också för att hejda den ekologiska miljöförstöring som trots heroiska insatser pågår $\mathrm{i}$ oförminskat tempo. I världskommisionens rapport är det utöver inledningsorden av kommissionens ordförande Javier Pérez de Cuéllar de centrala kapitlen om en global etik (kap.1) och en hållbar miljövision (kap.8) som tydligast innehåller ett paradigmatiskt budskap. De representerar en utmaning som reser exceptionella krav på kreativt nytänkande, inte bara inom kulturteorin och den praktiserade kulturen utan också på politikens och vetenskapens områden.

Oförmedlat vid sidan av det evolutionära anslaget figurerar en episk (i huvudsak 
inomparadigmatisk) tidsparameter. Dess reformtankar tjänar också ett framåtsyftande uppdrag som dock är bundet till det moderna projektets idéstruktur, inklusive dess post- och senmoderna varianter. Grundhållningen till modernitetens ekonomistiska vision är ogrumlat positiv och den förnyelse som man eftersträvar innebär en kulturell harmonisering till den samtida teknocivilisationen i dess fullbordade globala form. Vad man föreställer sig är i grunden ett av den nya informationsoch mediateknologin uppburet massamhälle. I dess mångkulturella vision blandas högt och lågt i ständigt skiftande kombinationer. Den estetiska kreativiteten söker sig nya vägar och ingår när det är lägligt allianser med den tekniska och ekonomiska kreativiteten. I rapporten är det främst de likaledes viktiga kapitlen om det pluralistiska åtagandet (kap. 2) och den massmediala utmaningen (kap.4) som redovisar en sådan accepterande, inomparadigmatisk tendens.

Slutligen intar det episodiska (kortsiktiga eller trendmässiga) perspektivet en så framträdande plats att också det betecknar en självständig temporal parameter. På denna nivå handlar det till en del om lanseringen av kulturellt och ideologiskt allmängods som hämtats från den samtida kulturpolitiken och aktuella trender. Det rör sig om kvalificerade teman, men de presenteras utan närmare bearbetning för det aktuella syftet - de är närmast okontroversiella. Kapitlen om genus och kultur (kap.5), om barn och ungdom (kap.6) samt om kulturarvet i utvecklingens tjänst (kap.7) kan i första hand hänföras till denna kategori. Men till gruppen hör också en rad rituella bugningar i riktning mot den ekonomiska samhällsmakten, som strötts över rapportens sidor. Sådana inslag misspryder särskilt prologer och epiloger i ett par kapitel. Här spikas kulturens emancipationsförsök fast med femtumsspik i den härskande maktstrukturen (se kapitlen Sammanfattning och Inledning).

Att offentliga utredningar i vår tid har en fragmenterad och därmed kryptisk prägel är knappast ovanligt. Snarare utgör det kutym i det postmoderna samhället. För en erfaren läsare kan sådana texter ha ett högre sakligt informationsvärde än modernismens överdrivet glättade konsensus, som lätt bryter udden av kontroversiella budskap. Här presenteras ett åsiktstorg i vars sortiment den kreativa läsaren kan välja och vraka. Ändå är det intellektuellt otillfredsställande $\mathrm{i}$ en så viktig fråga som den vi avhandlar. Direkt problematiskt blir det när de divergerande begreppsvärldarna med jämna mellanrum glider i varandra och manipulativa tendenser gör sig gällande. Man kan - bara för att ta ett exempel - lätt föreställa sig att någon grupp faller för frestelsen att använda paradigmatiska argument för att förgylla en inomparadigmatisk reform som i slutändan bara ger större inflytande åt en etablerad tjänstemannakår och dess ordinarie program, särskilt i en situation när sektorns existens är hotad.

\section{TEMATISK BEGREPPSANALYS}

Att hantera offentliga utredningar som orakelsvar förblir ur sakliga synpunkter ohållbart. I det aktuella fallet är det inte heller nödvändigt eftersom texten tycks öppna sig för en epistemologisk djupanalys. Men vi har ännu inte nått botten av en sådan. Också användningen av de 
PER R \& B E R G

122 grundläggande begreppen förtjänar en närmare granskning. För att uppnå en allsidig belysning skall jag fortsätta min analys med att studera själva kulturbegreppets användning. Också här är min avsikt närmast logisk-filosofisk, att avslöja hur stor enighet som råder $\mathrm{i}$ begreppsdefinitionen samt påvisa om eventuella differenser grundar sig på reella eller fiktiva skiljaktigheter. Diskuterar man över huvud samma kultur i de olika kapitlen?

En begreppsanalys avslöjar ganska snabbt att kulturbegreppet av kommissionen används i tre olika betydelser. Jag klassificerar varianterna som ett värdekulturellt, ett sociokulturellt och ett pseudokulturellt perspektiv. De tre kulturbegreppen är till sin allmänna karaktär så olikartade att de måste betecknas som skilda kategorier och som i princip inkompatibla. I det moderna samhället materialiseras värdekulturen tydligast via den estetiska kulturen, som bildar en väldefinierad sektor. Men värdekulturen omfattar i själva verket en lång rad särpräglade sektorer med normativ betydelse för samhället och vår livsföring. Tillsammans utgör de själva essensen i vad vi betecknar som en humanistisk livsstil. Värdekulturens kraftkälla finns i den mentala substrukturen hos individen och i allmänna medvetandet. Därifrån påverkas inte bara den subjektiva livsföringen utan hela samhällssystemet. Samtidigt återverkar normerna på individnivån $\mathrm{i}$ en löpande feed-backprocess. De receptionspsykologiska aspekterna av denna interaktion beskrivs bäst $\mathrm{i}$ fenomenologiska termer. I rapporten är det närmast det kraftfullt framförda etiska imperativet som hänför sig till värdekulturens sfär (kap.1).

Det sociokulturella begreppet är relaterat till den sociala interaktionen mellan individerna i ett samhälle och de informationsmängder som kommuniceras mellan dem med verbala eller tekniska metoder. Under denna process skapas de mytem och meningsbärande myter som bildar ett samhälles kultur i antropologisk betydelse. Semiotiken är i stora stycken en utmärkt metod för att vetenskapligt analysera dessa kommunikativa processer, och utgör grunden i den strukturalistiska och poststrukturalistiska teoribildning som dominerar inom socialvetenskapen. Emotiva och estetiska metaforer färgar ofta den sociala kommunikationen, men tjänar i första hand som ett smörjmedel. Även om gränsöverskridande fenomen uppträder, hänför sig det sociala kulturbegreppet till en annan kognitiv och existentiell sfär än den estetiska-värdekulturella. Det studeras bäst inom den sociala livssfär som är antropologins, sociologins och socialpsykologins forskningsområde. Deras meningsanalys och semiotiska metodologi är kongeniala i detta sammanhang och konkurrerar principiellt inte med det värdekulturella begreppet och dess hermeneutiska förståelsesystem. I den aktuella boken dokumenterar särskilt Inledning och kapitel 2 Ett åtagande för pluralism - ett sådant synsätt. Men ett antropologiskt synsätt präglar i själva verket stora delar av boken

Slutligen urskiljer vi det pseudokulturella begreppet. Det borde inte vara nödvändigt att förklara detta begrepp närmare. Det ringar in ett välkänt fenomen $\mathrm{i}$ den moderna teknocivilisationen. I avsaknad av ett genom den kreativa konsten och filosofin klart artikulerat värderande kulturbegrepp är fältet sedan länge fritt för vem som helst att formulera sig på området utan att riskera repressalier. Det är en 
situation som har utnyttjats av många intressegrupper och politiska strömningar utan att de haft verklig täckning för tilltaget. Den funktionalistiska arkitekturteorins slagord «det ändamålsenliga är det sköna» är bara ett exempel på detta slags missbruk. Human- och samhällsvetenskaperna utgör inget undantag, tvärtom har de gått i spetsen för flera försök att legitimera pseudokulturella teorier, gärna då med scientistisk framtoning. I den samtida kulturteorin måste ett frågetecken sättas för vissa strukturalistiska ansatser, både vad angår deras relativiserande kunskapsteori och deras från lingvistiken (Saussure) inspirerade metodik. Detta gäller närmast när (post)strukturalismen gör anspåk på giltighet inom den genuint värdekulturella sfären eller - tvärtom - avser att detronisera denna. I det senare fallet råder ingen tvekan om att tilltaget representerar en antikulturell för att inte säga antihumanistisk tendens. Strukturalistiskt inspirerade kommentarer dyker sporadiskt upp i rapporten. Särskilt i kapitel 3 - Kreativitet och makt - vädras pseudokulturella attityder. Det är svårt att avgöra hur långt de antiestetiska (eg. teknorationella) aspirationerna sträcker sig i det enskilda fallet.

\section{FINAL MALLANALYS}

Analysen av teoretiska tidsramar och kulturbegreppets betydelse är till stor hjälp när det gäller att kartlägga fasetterna i världskommisionens rapport och precisera de disparata budskapen. Men för att uppnå en realistisk avvägning mellan betydelsefälten måste vi också beakta deras roll i den övergripande kontexten. Jag skall därför avsluta granskningen med att utsätta kommissionens idéprogram för en helhets- analys. En lämplig utgångspunkt är kapitel 9 En omprövning av kulturpolitiken.

Redan en hastig blick avslöjar att det är den multikulturella visionen som ställts i centrum för ansatsen. En totalt ny vision måste vägleda den framtida kulturpolitiken, fastslår kommissionen. I fokus står inte längre den exklusiva konsten utan den breda populärkulturen som vänder sig till medborgaren i det globala massamhället. Den nya kulturpubliken utgörs emellertid inte av en hop passiva konsumenter, den är aktiv och medskapande och kommer från alla ålderskategorier. Den enskil$\mathrm{da}$ individens intention som kulturproducent är att uttrycka sina och livsregionens värderingar, och därigenom formar han samtidigt sin kulturella identitet. Ur dessa intentioner hos ett oöverskådligt antal individer och kollektiv uppstår ett pluralistiskt och mångkulturellt samhälle, där olika etniska grupper alla äger en unik röst. För att kommunicera de mångskiftande budskapen står en mängd gamla och nya medier till tjänst och särskilt de elektroniska massmedierna. Navet i den vitala dynamiken utgörs av de globala metropolerna med sin intensiva urbana livsstil. Detta är i sammandrag den vision som den radikala kulturpolitiken vill förverkliga, men inte genom hård styrning utan med efterfrågeprofilering av sina verksamheter. Tiden är nu inne att skrida från idé till handling, hävdar kommissionens visionärer. Genom visionens förverkligande kan kulturen förvandlas till en tongivande faktor i utvecklingen.

Hela den pluralistiska visionen påminner i sin grundidé om de folkliga kultursatsningar som i olika skepnad (participation, amatörism, folkbildning) länge har utgjort en sidogren till den klassiska kul- 
124 turpolitiken. Men medan denna präglades av en moralisk distans till den industriella masskulturen innebär den nya rörelsen ett mer eller mindre hängivet bejakande av industrikulturen och en aktiv vilja att av dess namnlösa arketyper skapa och etablera levande och tidsmässig kultur. Det är en hållningsändring som innefattar ett erkännande också av de ekonomiska krafter som skapat den moderna och postmoderna situationen och det globala samhället. Men den nya strömningen är inte helt okritisk i detta stycke. Förhoppningen är att genom politiska insatser kunna garantera att de participatoriska kraven säkras också i den sociala samhällsplaneringen. Den nya kulturpolitiken framträder i sin politiska helhetsvision ibland som talesman för en humanistisk socialism av klassiskt snitt.

Den kulturella pluralismen är givetvis ingen skapelse av den kulturella världskommissionens expertgrupp. Den är en produkt av de senaste decenniernas internationella kulturdebatt inom olika medier och vid universiteten. Mellan raderna skymtar i rapsodisk form tankefragment från de tongivande aktörerna inom postmodernism, dekonstruktion och poststrukturalism samt bakom dem strukturalism, lingvistik och semiotik. Det är teoretiska ansatser som făr sin speciella färgning genom de vetenskapliga discipliner som brukat dem för sina syften: antropologi, sociologi, politisk historia, statsvetenskap, museologi, mediaforskning samt givetvis de centrala kulturämnena konstoch litteraturvetenskap. De flesta av dessa konkurrerande riktningar, även den socialistiska, förenas i begreppet cultural studies, som på senare år har etablerats som akademisk disciplin vid olika universitet.
Cultural Studies utgör ett progressivt initiativ framför allt genom sitt försök till tvärvetenskaplig kraftsamling i kulturstudierna. Ur dagens eklektiska ansatser kan sannolikt intressanta synteser uppstå som medför en förstärkning av hela kulturområdet - det beror bl.a. på den inneboende kreativiteten hos fältet.

I en utvärdering av det kulturpolitiska kapitlet måste den stora frigörande betydelsen hos den nya kulturvisionen premieras. Den globala industri- och populärkulturen är sedan länge ett faktum och de traditionella gränslinjerna mellan högt och lågt har för länge sedan övergivits både av kulturproducenter och kulturkonsumenter. Det är hög tid att också kulturpolitiken tar de fulla konsekvenserna av denna utveckling och undersöker möjligheterna till ett inspirerat bidrag. Det är likaså positivt att man inser nödvändigheten av att engagera human- och samhällsforskningen i förnyelseprojektet. Särskilt i ett medellångt perspektiv finns utmaningar som kräver medverkan av alla progressiva energier för att bryta status quo.

Men vid sidan av den positiva läsarten finns utryme för en annan mera kritisk, som vi också måste hålla i minnet. Det föreligger t.ex. en märklig klyfta mellan praxis och teori i det nya kulturpolitiska utspelet. Synen på kulturens praxis är tydligt färgad av ett estetiskt värdeperspektiv med tonvikt på den nya värld av kvalitativa artefakter som industrikulturen frambringat. Den teoretiska visionen hämtar istället sitt stoff från en sociokulturell sfär, som närmast inspirerats av antropologins livsformsbegrepp och lingvistikens kommunikationsteorier. Det är ofta svårt att avgöra huruvida apologeterna prioriterar sina teorier eller den praxis som de hänvisar till. 
Om tyngdpunkten i programmet läggs på teoriavsnittet finns det viss anledning till oro. Vid ett kritiskt betraktande blir det uppenbart att ett antiestetiskt budskap droppar in i texterna på flera ställen - om detta är medvetet eller omedvetet låter jag vara osagt. Det schablonmässiga avfärdandet av konstkulturen som klasstämplad elitism inger farhågor när man inser i vilken grad det estetiska skapandets livskällor hotas i det sena teknosamhället. Och det entusiastiska bejakandet av den globala informationskulturens socialestetiska möjligheter slår ganska ofta över i ett förbehållslös bejakande av det moderna tekniksamhället som absolut framtidsvision. I den nya kulturteorin - och särskilt dess poststrukturalistiska bidrag - framträder starka mekanistiska - för att inte säga antihumanistiska - drag som pekar mot en alienerad teknologisk modell. (Belysande exempel på de olika tendenserna finner den intresserade i John Storey's antologi Cultural theory and popular culture. $A$ reader (1998), som utgör en aktuell exponent för Cultural studies.)

Med den kritiska läsarten framträder en bild som tycks diametralt motsatt det positiva budskapet. Den globala populärkultur som man applåderar är nu en harmlös statist i utvecklingens drama, och klarar sin roll med eller utan kulturpolitikens stöd. Men på ett symbolplan gör den utmärkt tjänst som kulturell metafor för det härskande teknoparadigmet och legitimerar samtidigt dess universella anspråk. Att visionen haltar och läcker betyder inte så mycket, eftersom man har hela etablissemanget i ryggen. Med denna läsart liknar den multikulturella satsningen en populistisk pseudokultur och utgör helt klart en estetisk reträtt. - Det är en allvar- lig förhoppning att det blir den första, positiva läsarten som avgår med segern, och att modet finns att realisera dess socialestetiska budskap.

\section{VÄRDEKULTURENS PARAMETER}

Både i den positiva och negativa versionen företräder den sociokulturella trenden ett inomparadigmatiskt initiativ. Men rapporten innehåller också flera kapitel där ett gränslöst evolutionärt projekt formuleras. Vilka är de kulturpolitiska konsekvenserna av denna linje? Märkligt nog innehåller det politiska kapitlet ingen tydlig information om hur en paradigmatisk ansats skall omsättas i praktisk politik. Är detta ett tecken på att en konflikt råder inom världskommissionen och $\mathrm{FN}$ :s kulturpolitiska expertis? Oavsett om det handlar om tillfälligheter eller censur finns det goda skäl att påmina om det evolutionära projektets existens. I världskommissionens skrift markeras närvaron tydligt genom en närmast ideologisk programförklaring som ställer kulturpolitiken i spetsen för hela samhällspolitiken. Och de engagerade argumenten för en global etik $\mathrm{i}$ bokens inledningskapitel konfirmerar det allvarliga uppsåtet. I den efterföljande debatten har hävdats att tiden är inne att efter Riokonferensens förebild författa en Agenda 21 för kulturområdet. Begreppet hållbar kulturell utveckling ställs upp som ett riktmärke. Alla dessa tecken signalerar tydligt närvaron av en paradigmatisk intention i det kulturpolitiska FN-projektet och att den fortfarande hålls levande.

Eftersom den värdekulturella parametern ur humanistiska synpunkter utgör den mest progressiva nyheten i kommissionens program är det viktigt att den stan- 
126 nar på dagordningen och understöds med alla goda sakskäl som kan mobiliseras. Kanhända är det önskvärt att nya kompetensgrupper ges tillträde till expertdiskussionen. Framför allt är det viktigt att väl underbyggda argument tillförs, så att både realismen och nödvändigheten i projektet framträder tydligt. Eftersom jag bedriver forskning på området vill jag bidra med ett par synpunkter med förhoppning om att de kan nyttiggöras i den ännu oavslutade diskussionen om visioner för en global kulturpolitik.

Låt mig inleda med en kommentar till definitionsfrågan. Etikbegreppet, som kommissionen tar upp i sitt inledningskapitel, är givetvis en central aspekt i värdekulturen och används $\mathrm{i}$ äldre litteratur ibland som beteckning på hela området (se t.ex. Höffding 1913). Med begreppet värdekultur avser man idag det spektrum av subjektiva värderingar och sociala värdenormer som vägleder oss $\mathrm{i}$ vårt dagliga liv, men som också ger visst stöd $\mathrm{i}$ mer livsavgörande ögonblick. Dess kärna består av ett antal kvalitativa kriterier som individen internaliserat och använder vid bedömningen av livskvaliteten i samhället och formuleringen av värdiga mål för sitt liv. De representerar vårt samhälles humanistiska kapital och bildar ett seismografiskt känsligt instrument för att upprätthålla den existentiella systembalansen. I värdekulturens praxis utgör den estetiska kulturen ett omistligt inslag, vid sidan av de etiska värdena och våra moralbegrepp. I en annan sektor ryms de emotiva och altruistiska värden som är grunden för våra humanitära omsorger. Också de avancerade funktionella och logiska värdesystemen, samt de andliga och metafysiska systemen ingår $\mathrm{i}$ kretsen. I en global värde- kultur kan de inte förbigås, trots de tabueringar som Väst reflexmässigt anför mot begreppen. I de historiska kulturerna spelade religionen som bekant en central roll som upprätthållare av värdekulturens ideal. Det finns också en vetenskapsgren inom filosofin som utförligt behandlat de olika här berörda aspekterna inom värdeteorin: dess historiska benämning är axio$\log i$.

Vem ställer idag upp för att förvalta och förnya detta väldiga kulturarv, och existerar över huvud några slagkraftiga påtryckningsgrupper? Svaret är att de antagligen är betydligt fler än man skulle tro med ett konventionellt kulturellt synsätt. I vårt sammanhang är de märkligt osynliga, eftersom de inte är organiserade efter kulturella kriterier utan enligt andra fackliga och politiska principer. Men en hastig översyn visar att en stor kår av ideella krafter är verksam på alla nivåer av samhällslivet i uppgifter som ideologiskt tillhör värdekulturens breda humanistiska sfär. Detta ideella arbete bedrivs i vården och omsorgen, i kampen för fredsidealen och de mänskliga rättigheterna, mot våld och tortyr och folkmord, i striden för barnens, kvinnornas, minoriteternas och ursprungsbefolkningarnas legitimitet och lika värde, i den politiska argumentationen för en fördjupad demokrati och kulturella rättigheter, men också för andra arters existensberättigande och för en global naturetik. Det internationella samfundets högsta organ - FN och dess associerade institutioner - intar en central roll i kampen för den humanistiska värdekulturen vid sidan av en rad frivilliga organisationer och särskilt inrättade organ (jfr t.ex. FN:s deklaration om de mänskliga rättigheterna). 
Dagligen möts vi av bulletiner från dessa praktiserande humanister, som med skrämmande exempel dokumenterar hur de mänskliga och sociala grundvärdena i vår kultur utarmas och ödeläggs av nyckfulla eller organiserade krafter över hela världen. De avslöjar samtidigt hur svårt det är att bemöta och avvärja dessa destruktiva symtom, därför att de är nära förbundna med de ledande utvecklingsmakterna i vår epok. De humanistiska krafterna inom värdekulturen befinner sig $\mathrm{i}$ ett kroniskt underläge gentemot den humanitära dekonstruktionen. Detta är ett akut dilemma och inte bara för de humanitära aktörerna utan för hela samhället. Det är ett angrepp mot vår civilisations hjärttrakter och mot den grundläggande livsdynamiken.

Det existerar ingen samlad strategi för att hävda värdekulturen i denna breda humanistiska betydelse på ett övergripande politiskt plan. Teknorationalitetens växande hegemoni i det senmoderna samhället provocerar emellertid frågan om det inte är hög tid att också formulera gemensamma strategier till de humana värdenas försvar på en övergripande nivå. Nya handlingsorienterade program och institutioner behövs för att omsätta den humanistiska ideologin - som redan i ett halvt sekel odlats inom delar av FN-systemet till social verklighet. Om vi ser till den institutionella situationen konstaterar vi att den estetiska kulturen är den enda sektorn i värdekulturen som bildar ett självständigt politikområde. Den just nu aktuella UNESCO-diskussionen väcker emellertid osökt tanken att den kulturpolitiska arenan - i utvidgad form - kanske kan tjäna som organisatorisk ram också för ett hävdande av värdekulturen. Detta är en tanke som under alla omständigheter borde prövas närmare.

Men för att en sådan idé skall kunna realiseras räcker det inte med institutionsbildning och erfarenheter från praktiskt fältarbete. Det är nödvändigt att skapa en teoretisk underbyggnad som klargör värdekulturens roll i människans identitet och plats i samhället, och som öppnar en vetenskaplig diskussion om en kulturteori för hållbar utveckling. Ett viktigt led i den vetenskapliga kompetensuppbyggnaden är att förkovra sig i filosofins värdeteori sådan den utövas idag och utövades av de nästan glömda historiska föregångarna (Immanuel Kant utgör det stora undantaget). Axiologi har knappast varit ett ämne som stått högt i kurs i den logiska positivismens era och inte heller under postmodernismen. Efter nästan ett sekels tystnad har emellertid värdeteorin på senare år upplevt en akademisk renässans. (John Rawl's A Theory of Justice från 1971 var en viktig utlösande faktor.) Särskilt intressant är den nya epistemologiska diskussionen, där allvarliga försök pågår att övervinna den dogmatiska relativismen och skapa respekt för den värdeteoretiska analysen som en empirisk-vetenskaplig kunskapsväg. Det finns goda skäl att peka på denna nya trend inom humanvetenskapen och att initiera en målmedveten forskning på området. Att utforma en väl underbyggd värdeteori för det globala framtidssamhället är den stora utmaningen.

En forskning med sådan inriktning pågår i själva verket redan vid en del universitet. För att visa hur den kan gestalta sig skall jag ge ett konkret exempel. Det hänför sig till ett forskningsprogram som bedrivs under min ledning inom Avdelningen för kulturekologi vid Umeå uni- 
128 versitet. Hållbar social och kulturell utveckling är temat för detta program och de inledande resultaten har nyligen redovisats i boken The Life Region. The Social and Cultural Ecology of Sustainable Development (Routledge 1997).

\section{DET EKOLOGISKA PARADIGMET}

En teoretisk grundval för mitt diskussionsinlägg utgör det ekologiska betraktelsesättet. För att skapa full förståalse inleder jag med en kort bakgrund som klargör kopplingen till det ekologiska paradigmet och diskussionen om hållbarhet. Det är till att börja med - viktigt att inse att begreppet «det ekologiska perspektivet» inte är synonymt med «den moderna miljörörelsen». Båda representerar en framtidsvision, men den ekologiska tanken är ideologiskt och begreppsligt avsevärt bredare än de senaste decenniernas «environmentalism». Dess huvudtes är att interaktionen mellan de levande organismerna och deras omvärld utgör en grundprincip för livets organisering på vår planet och för en förståelse av arternas livssystem. Livssystemens väg genom evolutionen med de omväxlande progressiva och patologiska förändringar som inträder utgör ett tema för ekologin som vetenskapligt studium. I detta innefattas också människans framsteg som individ och art. Från den ekologiska utsiktspunkten kan man tydligt se att människans ekosystem råkat ur balans och är fångat $\mathrm{i}$ en process som utgör ett hot inte bara mot den yttre biomiljön utan mot artens eget liv. När den ekologiska tanken har förmått fängsla så många $\mathrm{i}$ de senaste decenniernas debatt och alternativrörelser är det djupast sett för att den avslöjar detta livshot samtidigt som den genomskådar den mekanistiska ordning som framkallat det patologiska tillståndet. När alternativrörelsen gick till strid var det en kamp för livet som det gällde, livet som essens och som samhällsmyt. Det var också ett personligt ställningstagande, som bottnade $\mathrm{i}$ insikten att de externa hoten faktiskt riktades mot livskärnan inom individen själv.

Ekologismens offentliga framträdande skedde tidigast i miljödebatten, där de livsfientliga effekterna var lätta att registrera och skapa debatt omkring. Miljöengagemanget blev en symbolfråga för den ekologiska vitalismen, och en katalysator där oppositionen mot den etablerade ordningen kunde ges utlopp. I detta klimat tog miljörörelsen fart, och assimilerades så småningom av de offentliga samhällsorganen. Riokonferensen 1992 och dess handlingsplan - Agenda 21 - är den hittills mest betydelsefulla manifestationen av den pragmatiska ekologismen. Men när rörelsen tog steget från ideologi till praxis ledde det genom uppgifternas storlek till att miljöfrågorna kom att dominera debatten, till den grad t.o.m. att den underliggande ekologiska ideologin försvann ur sikte. Rörelsen blev reformistisk och samhällstillvänd där den tidigare varit radikal och paradigmatisk.

Men redan tidigt hade en socialekologisk rörelse uppstått, med amerikanen Murray Bookchin som en av förgrundsgestalterna. Inom denna falang var det de sociokulturella krissymtomen i själva samhällskärnan som utgjorde brännpunkten. Också människans samhälle kunde studeras som ett ekosystem, och dess harmoniska utveckling eller patologier kunde regleras med hjälp av ekologisk teori och metod. Som ett bidrag till denna nya 
tematik, vars vetenskapliga fält till omfånget knappast är mindre än miljösektorn, inledde jag själv 1980 ett flerårigt projekt vars syfte var att formulera indikatorer för en hållbar social utveckling (se Råberg 1987). Utgångspunkten för mitt studium var en ekologisk hypotes, där relationen människa-samhälle avtecknade sig som ett interaktionssystem i flera nivåer. De olika nivåerna speglade framsteg som uppnåtts under en långvarig systemevolution. Själva koden för interaktion var förborgad i människans ekologiska identitet med dess korresponderande nivåer. På basis av dessa teorier skisserades $\mathrm{i}$ ett modellexperiment en helhetsvision av ett socialekologiskt hållbart samhälle (se Råberg 1997).

\section{KONTURER TILL EN EKOLOGISK VÄRDETEORI}

Den senaste fasen i den ekologiska tankens fördjupning utgörs av insikten om den centrala roll som ett värdeperspektiv spelar i individens ekologiska identitet, både som drivfjäder för livsprocesserna och instrument för en utvärdering av aktiviteten. Värdeperspektivet representerar i denna uppgift det grundläggande kvalitativa omdömet hos det ekologiska subjektet, och är ett oumbärligt instrument för att upprätthålla balansen mellan externa behov och mänskliga resurser. I människans personlighet är det subjektiva värderingssystemet nära förbundet med ekoidentiteten, och har en hierarkisk uppbyggnad som är synkron med denna. Det medverkar löpande i ekosamhällets dynamik och bidrar till att styra denna mot de optimala subjektiva, sociala och kulturella målen.
Det ekologiska projektet har därmed förflyttat sig den långa vägen från renaste naturvetenskap till kulturell djupanalys. Fast det är kanske riktigare att säga att det har överbryggat den artificiella klyftan som existerar mellan ytterligheterna. Jag kan inte här redovisa hur detta studium, som i den aktuella fasen spänner mellan fenomenologisk psykologi och mikronevrologi, har utvecklats till hypoteser om det mänskliga medvetandets evolution och beteende. Men jag vill här i korta drag redovisa den värdeteoretiska skissen. Den må fungera på sina egna funktionella meriter, och är i varje fall empiriskt inte sämre underbyggd än någon av de kulturteorier som $\mathrm{i}$ dag rutinmässigt figurerar $\mathrm{i}$ debatten. En presentation tjänar under alla omständigheter syftet att rikta uppmärksamheten mot ett problemfält som snarast bör ställas i centrum för den framåtblickande kultur- och utvecklingsdebatten.

Låt mig nu kortfattat karaktärisera människans existentiella värdesystem och de fem mentala värdenivåer som den kulturekologiska teoriansatsen i Umeå anser sig kunna urskilja. De fem nivåerna representerar värdemässiga toppkategorier och var och en av dem bildar ramen kring ett rikt och differentierat interaktionsfält.

\section{DE EXISTENTIELLA \\ VÄRDERINGARNAS SYSTEM:}

\section{- Det emancipatoriska värdesystemet}

Emancipation betyder frigörelse. I den kulturekologiska hypotesen betecknar termen en grundläggande drift hos människan till utträde ur den personliga identiteten och emotiv identifikation med den omgivande ekosfären, betraktad som livs- 
130 källa och helhetsram för de jordiska livsyttringarna. I denna drift, som är knuten till naturidentitetens basnivå i ekoidentiteten, uttrycks subjektets insikt om den djupaste rangordningen $\mathrm{i}$ naturen liksom i den ekologiska interaktionen mellan individ och omvärld. Kanske har beteendet sitt ursprung i det planetariska livets ursprungsstadium där det utgjorde en funktionell strategi för livsuppehället. Hos människan uppträder driften i sublimerad form och utgör ett instrument för hennes strävan till ekosfärisk helhetsorientering. Men med den medvetandenivå som människan uppnått har världsbilden vidgats långt över det lokala och globala rummets gränser. Vi lever i en kosmisk tidsålder och människans liv är ytterst underkastat en kosmisk ekologi och dess lagar. Strävan till existentiell och kosmisk helhetsidentifikation får hos individen sin utlevelse $\mathrm{i}$ djupt emotiva kategorier. I de historiska kulturerna förverkligades den ofta genom de religiösa myterna och utlades i metafysiska termer. I dag har gränserna suddats ut. Naturvetenskapen har påvisat att det är denna metafysiska värld som vi faktiskt lever i. Vi börjar inse att vi själva är en del av myten, att vi kreerar en roll $i$ «det evigas ekologi".

\section{- Det empatiska värdesystemet}

På det ekologiska värdesystemets andra nivå är det artidentitetens intressen som sätter ramarna, och den sociala gemenskapen som är målet. Den indivuella motivationen skapas genom en drift till identifikation med artfränderna som finns nedlagd i människans psyko-ekologiska konstitution. Också i detta fall registreras motivation och behovstillfredsställelse som emotiva förnimmelser över en bred och nyansrik skala. Begreppet "empati» uttrycker ganska väl hur den sociala identifikationsprocessen förlöper. Det sker genom «inlevelse i en annan persons känslor». Det är relativt lätt att föreställa sig hur det empatiska interaktionsmönstret $\mathrm{i}$ arternas gryningstimma (i rudimentär form) tjänat som den förbindande länken mellan individerna, och därmed säkrat reproduktionen och bildandet av populationer. På människans utvecklingsstadium är det kärlekens, omsorgens och vänskapens djupt inspirerande värden som förmedlas. Det grundläggande budskapet är fortfarande detsamma: att värna om artens intressen och ytterst om dess överlevnad. Drömmen om den lokala gemenskapen och det goda samhället hör till de myter som den empatiska värdeidentiteten odlar. I humanistiska termer kan man beskriva det empatiska värdesystemet som "det godas ekologi».

\section{- Det estetiska värdesystemet}

"Det skönas ekologi» utgör en tredje humanistisk kategori. Den utspelar sig på den sensoriska egoidentitetens nivå $\mathrm{i}$ det subjektiva ekosystemet. Egoidentiteten representerar i rang den tredje av de ekologiska identitetsnivåerna och sinnesförnimmelserna spelar här en förgrundsroll som motivationskälla för omvärldskontakten. Hos människan är den funktionella kopplingen troligen mindre rigid än i tidigare stadier och sinnesförnimmelserna via olika stimuli har i hög grad ett egenvärde. Men genom sin omedelbara påtaglighet utgör sinnesvärlden ett kraftcentrum i det subjektiva värdesystemet, det bildar ett eget rike med schatteringar, nivår och vida förgreningar. Dess bas består av de elementära förnimmelser som är knutna till 
de fysiologiska behoven, men däröver reser sig ett landskap av emotiva informationer och konnotationer som har bäring på den sociala livssfären. Som en yttersta nivå välver sig den estetiska sfären och bildar arenan för en rad helhetsbekräftande förnimmelser som utgör kärnan i det estetiska livet. Detta är en sfär som den samtida vetenskapen alltid haft svårt att komma till rätta med i sina analyser. Den motsvarar närmast en fenomenologisk verklighetsbeskrivning som vetenskapligt ännu befinner sig i sin linda.

\section{- Det etiska värdesystemet}

Sökandet efter det moraliskt rätta är den etiska värderingens uppgift. Det är en typ av värdeekologi som nog har ett modernare ursprung än de tidigare nivåerna. Den hänför sig till ett evolutionsstadium där samhällssystemet blivit så komplext att ett artikulerat normsystem behövs för att kunna hävda de existentiella värdena. Detta är människans avancerade livsnivå (teknorationalitetens nivå) och det nya instrument som avlöser den ekologiska intuitionen som tolkningsinstrument är den rationella diskursen. Med hjälp av rationell reflektion lyfts de existentiella grundvärdena fram ur sitt lokala sammanhang och översätts till humanistiska värdenormer för det kosmopolitiska samhälle som teknorationaliteten skapat. De etiska värdesystem som omfattas av vårt samhälle företräds av en lång rad ideella organisationer. Deras uppgift är att försvara de mänskliga rättigheterna, att säkra demokratin, att utveckla en fredskultur, att bekämpa våldet och försvara den globala freden, att värna om etniska minoriteter och ursprungsbefolkningar, att skydda andra arters rättigheter, och att bevara den globala biosfären och människans kulturarv. Förenta Nationena och en rad organ inom FN-familjen har länge intagit en förgrundsroll i det humanitära och etiska mobiliseringsarbetet. Som medborgare möter vi norm- och värdesystemen främst i staternas lagstiftning och rättsväsendets ordningar. I den juridiska principdiskussion som ständigt pågår intar de etiska idéerna en huvudroll. Sporadiskt aktiveras en moralfilosofisk diskurs från de akademiska tribunerna. - Vi kan också beteckna denna fjärde nivå i en radikal vetenskaplig humanism som "det rättas ekologi».

\section{- Det explorativa värdesystemet}

Termen "explorativ» betyder utforskande, med tonvikt på den vetenskapliga konnotationen. Jag använder här termen som metafor för det idealistiska sanningssökande som präglar den klassiska vetenskapssynen. I värdekulturens evolutionära spektrum har vi därmed nått fram till nutiden, rentav till den filosofiska frontlinje som blickar in i framtiden. Den värdediskussion som utspelar sig här gäller rationaliteten, och rationaliteten inte främst som vetenskaplig metod för att lösa problem, utan som mänsklig passion och utvecklingsideal. Denna inställning kännetecknar logoidenteten, som i vår modell beskrivs som ekoidentitetens funktionellt sett mest avancerade nivå. Det absoluta sanningsvärdet är logoidentitetens hägrande mål och i vetenskapshistorien är det snarare de grekiska filosoferna än den moderna vetenskapen som företräder ett sådant ideal. Till skillnad från den senares metodiska tekno-rationalitet representerar logorationaliteten en universell rationalitet som utnyttjar samtliga kognitionsnivåer $\mathrm{i}$ människans medvetande, också den senso- 
132 riska och instinktiva informationen. Viljan till sann kunskap om verkligheten skapar motivationen, och upplevelsen av världsbildens förklaring och vårt medvetandes fördjupning är belöningen och det kulturella värdet. Den logiska värdekulturen står inte $\mathrm{i}$ någon motsättning till de andra kategorierna $\mathrm{i}$ värdekulturen, utan bejakar och hämtar sin inspiration från dem. Genom sitt holistiska sanningskrav väcker värderationaliteten ett framtidshopp och en tro på människans värdiga överlevnad som inga andra strömningar i samtiden lyckats inge oss. - Som den funktionella höjdpunkten i det humanistiska normsystemets hierarki placerar vi "det sannas ekologi".

\section{STRATEGI FÖR EN GLOBAL KULTURPOLITIK}

Men på vilket sätt kan en normativ modell av värdekulturen (t.ex. den här redovisade) nyttiggöras i samhället? Allra först givetvis genom att ruska om i kulturdebatten, som idag är totalt hängiven föreställningen om kultur- och värdebegreppens relativitet och pluralism, vilket gör blotta tanken på en normativ värdeteori till ett brott. Det vore ett stort vetenskapligt framsteg - till fromma för samhället - om det humanistiska tankeförbudet kunde hävas och den normativa reflektionen bereddes en legitim plats i kulturdebatten. För det andra utgör en normativ modell ett stöd för den humanitära utvecklingsdebatten och dess praxis genom sin blotta existens. Den kan ingjuta mod och ny tillförsikt hos en hårt prövad kår, vars insatser och ideal ständigt ifrågasätts och som kämpar en hård strid för de allra nödvändigaste resurserna. Den idealistiska retorik med vilken den humanitära rörelsen försvarar sina positioner erhåller ett mer substantiellt och auktoritativt innehåll. För det tredje kan den normativa diskursen ge viktig kreativ input till de enskilda värdesektorernas arbete och bidra till en precisering av deras praxis. För det fjärde är förhoppningen att modellen förmår inspirera till en internationell diskussion om gemensamma politiska insatser och institutioner på det humanistiska området. FN kan inte i längden ensam stå som garant för humanismen och de humanitära idealen i världssamhället. Låt mig här stanna vid denna hastiga uppräkning.

Lika viktigt som alla dessa etableringsfrågor är att ett kreativt forsknings- och utvecklingsarbete kommer igång som fullföljer de tankespår som dragits upp, eller kanske lägger helt nya spår. Det föreligger ett trängande behov av ny värdeteoretisk kunskap och uppdatering av delvis glömd kunskap. Helst bör sökandet bedrivas från ett vetenskapsperspektiv som befriat sig från de otidsenliga tabun och direkt antivetenskapliga dogmer som belastar en del av modernismens och postmodernismens teorier. En stor procent av insatsen bör ges grundforskningskaraktär och sikta mot en kartläggning av de elementära mänskliga behoven och samhällsvärdena. Man făr nog räkna med att ansatsen under en inledningsfas kommer att motarbetas av en akademisk maktelit som utan skrupler försvarar status quo mot den vetenskapliga frontlinjen, för att i rätta ögonblicket i god totalitär tradition annektera området. Det är därför viktigt att aktörerna på fältet blandar sig i diskussionen och räddar de progressiva initiativen, kanske genom att skapa egna forskningsinstitutioner. 
I den här uppsatsen är det emellertid FN-initiativet för kultur och utveckling och dess kulturpolitiska reformförslag som står i fokus. Vi skickar därför våra synpunkter vidare till detta forum med en uppmaning att i sitt slutdokument beakta önskemålet om relevanta plattformar för samtliga vitala rörelser i samtidens kulturella spektrum. I en samhällssituation där kulturen och kulturmedvetandet trängs allt hårdare från olika håll, finns det inte utrymme för sekteristiska schismer mellan olika tankeriktningar, särskilt om en analys visar att de i sak inte nämnvärt konkurrerar med varandra. Detta gäller lika mycket inom kulturpolitiken som i den kulturvetenskapliga forskningen. Förhoppningen är att FN:s projektansvariga själva är kapabla att inta en pluralistisk hållning, som vid sidan av populärkulturen ger plats dels för den professionella konstkulturen (som behandlats skäligen styvmoderligt $\mathrm{i}$ förarbetet), dels för den existentiella värdekulturen, som särskilt förtydligas i mitt debattinlägg. Alla progressiva förnyelseprojekt måste samverka om kulturen skall ha en realistisk chans att inta den prominenta position i centrum av politik och samhälle som FN-projektets initiativtagare drömmer om.

\section{REFERENSER}

Attfield, R. (1987): A theory of value and obligation. Croom Helm, New York.

Bertilsson, M. och Carlheden, M., Red. (1995):

Det goda livet. Etik $i$ det (post)moderna sambället. Symposion, Stockholm.

Brülde, B. (1998): The human good. Acta

Universitatis Gothoburgensis. Göteborg.

Connor, S. (1992): Theory and cultural value.

Blackwell, Oxford. van Deth, J.W. and Scarbrough, E., Eds. (1995):

The impact of values. Oxford University Press, Oxford.

Duelund, P. (1994): Kunstens vilkår - om de kulturpolitiske tendenser i Danmark og Europa. Akademisk Forlag, Köpenhamn.

European Task Force on Culture and Development (1997): In from the margins. A contribution to the debate on culture and development in Europe.

Council of Europe Publishing, Strasbourg.

Fornäs, J. (1995): Cultural theory and late modernity. Sage, London.

Frey, R.G. and Morris, C.W., Eds. (1993): Value, Welfare and Morality. Cambridge University Press, Cambridge.

Hermerén, G. (1988): The nature of aesthetic qualities. Lund University Press, Lund.

Höffding, H. (1913): Etik. 4. uppl. Gyldendalske Boghandel, Köpenhamn.

Kant, I. (1964) Groundwork of the metaphysic of morals. Harper Torchbooks.

Kleinig, J. (1991): Valuing life. Princeton University Press, Princeton.

Kulturpolitik for utveckling. Svenska Unescorådets skriftserie nr 3/1998.

Kulturpolitikens inriktning. Slutbetänkande av Kulturutredningen. SOU 1995:84. Fritzes, Stockholm.

Kurtines, W.M. m.fl, Eds. (1992): The role of values in psychology and human development. John Wiley \& Sons, Toronto.

Lemos, N.M. (1994): Intrinsic value. Cambridge University Press, Cambridge.

Lemos, Ramon M. (1995): The nature of value. Unversity Press of Florida, Gainesville.

Masters, R.D. (1993): Beyond relativism. Science and human values. University Press of New England, Hanover (NH).

Milton, K. (1996): Environmentalism and cultural theory. Routledge, London.

Rawls, John (1971): A theory of justice. Harvard University Press, Cambridge (Ma). 
134 Råberg, P. (1987): The Space of man. New concepts for social and humanist planning. Acta Universitatis Umensis, Umeå.

Råberg, P. (1996): Ekologi som kulturvetenskap En radikal utmaning för museerna. Nordisk Museologi 1996:2, Umeå.

Råberg, P. (1997): The life region. The social and cultural ecology of sustainable development. Routledge, London.

Singer, P. Ed. (1994): Ethics. Oxford University Press, Oxford.

Storey, J. (1997): An introduction to cultural theory and popular culture. Prentice Hall, London.

Storey, John, Ed. (1998): Cultural theory and popular culture. A reader. 2.ed. Prentice Hall, London.

Tjugo års kulturpolitik 1974-1994. En rapport frän Kulturutredningen. SOU 1995:85. Fritzes, Stockholm.

Vestheim, G. (1995): Kulturpolitikk i det moderne Norge. Det Norske Samlaget, Oslo.

Världskommissionen för kultur och utveckling (1996): Vår skapande mångfald. Norstedts Tryckeri AB, Stockholm.

\section{SUMMARY}

\section{Cultural Policy and a Value-oriented Culture}

The author comments upon the UN report Our Creative Diversity initiated by the World Committee on Culture and Development (1995) and the study In from the Margins published by the European Council of Culture in 1997. An attempt is made to analyse the various concepts of culture used and to disentangle the seemingly contradictory applications offered as instruments for global development. An alternative approach to the problem is suggested which takes as its point of departure the idea proposed by the World Commission to put cultural policy at the head of global development ( it has been proposed that a counterpart to Agenta 21 of the Rio Conference should be established in cultural policty). It is shown how a culture of values could be derived from the theory of a social and cultural ecology for sustainable development. This theory has already been outlined in Nordisk Museologi 1996/2, pp. 71-86. The theory encompasses the development of five levels of values inherent in all human beings - emancipatory, empathetic, esthetic, ethic and exploratory value systems. The paper ends with an insistent appeal for a debate about a normative value-oriented cultural policy must be given priority.

Per Räberg är docent och forrestaindare for Avdelningen for kulturekologi. Han är knuten till Institutionen for museologi, Umeå universitet.

Adr: Institutionen for museologi, Umeå universitet, S-90187 Umeå

Fax $+46-907867845$ 